\title{
Varietal differences in growth, development and tuber production of potatoes
}

\author{
H. D. Gmelig Meyling and K. B. A. Bodlaender \\ Centre for Agrobiological Research (CABO), Wageningen, the Netherlands
}

Accepted: 5 January 1981

Key words: potato varieties, growth rate, stem growth, dry matter distribution, growing periods, leaf area duration, tuber production

\section{Summary}

With a limited number of varieties a comparative study was carried out on growth and development in relation to tuber production.

The results obtained demonstrated that genetic yield differences (differences in productivity) are not caused by one single growth or development parameter. The intervarietal yield differences were distinctly associated with genetic differences in, for example, leaf efficiency and size of the leaf apparatus, rate of stem growth and stem development and varietal earlines and were also affected by weather conditions.

The earlier varieties, in general, were characterized by a higher growth rate and a favourable dry matter distibution in the first part of the growing period (June and July). On the contrary, productivity of the later varieties was especially enhanced by a longer Leaf Area Duration (LAD). This was a result of the slower senescence of the foliage in the second part of the growing period (August and September). The importance of the relation between stem and tuber growth was more distinct, whereas favourable tuber/stem ratios were found to be independent of varietal earliness.

\section{Introduction}

Earlier investigations of potatoes have brought forward several basic facts on growth and development of this crop (Wittenrood et al., 1957; Engel \& Raeubert, 1962, 1964; Nečas, 1965; Bodlaender, 1978; and others).

The present study deals with the question whether genetic differences in growth and development are related to intervarietal yield differences.

During three years, growth and development of a limited number of varieties were studied in relation to tuber yield in field experiments. 


\section{Material and methods}

According to the Dutch List of Varieties of Agricultural Crops (Anon., 1969) the varieties studied belong to the following earliness groups, in which decreasing earliness is indicated by a lower figure: 5 for Mentor and Irene, 4 for Alpha and 3.5 for Pimpernel. In addition to these four varieties a number of other varieties were included in the experiments during two years, viz Noordeling (earliness 6) in 1968, Prudal (earliness 7) in 1968 and 1969 and Bintje (earliness 7) in 1969.

The experiments were carried out in triplicate on sandy soil with a high organic matter content at Varsseveld (in the eastern part of the Netherlands) during the years 1967, 1968 and 1969. A nitrogen dressing of $200 \mathrm{~kg}$ per ha was applied in all three years, while plant density in 1967 and 1968 was 60000 plants per ha and 62500 plants per ha in 1969. Presprouted seed tubers in the size $35 / 45 \mathrm{~mm}$ were planted in April.

From the end of May until the end of September/beginning of October three plots of each variety were lifted every two weeks and separated into leaves and stems, underground parts ( $=$ underground stems, stolons and roots) and tubers. Fresh and dry weights were determined of all plant parts.

For the distribution value of the dry matter in favour of the tubers (DT) the ratio between tuber dry matter increase and total dry matter increase was used. As a measure for the size of the leaf apparatus during a certain period Leaf Area Duration (LAD) was applied. LAD is: average LAI $\times$ number of weeks.

\section{Weather conditions}

Fig. 1 shows for the three experimental years the average global radiation, temperature and total rainfall in June, July, August and September. In 1967 average radiation was fairly high, average temperature in July the highest with respect to both other years, while rainfall in June, July and August was rather low. The year 1968
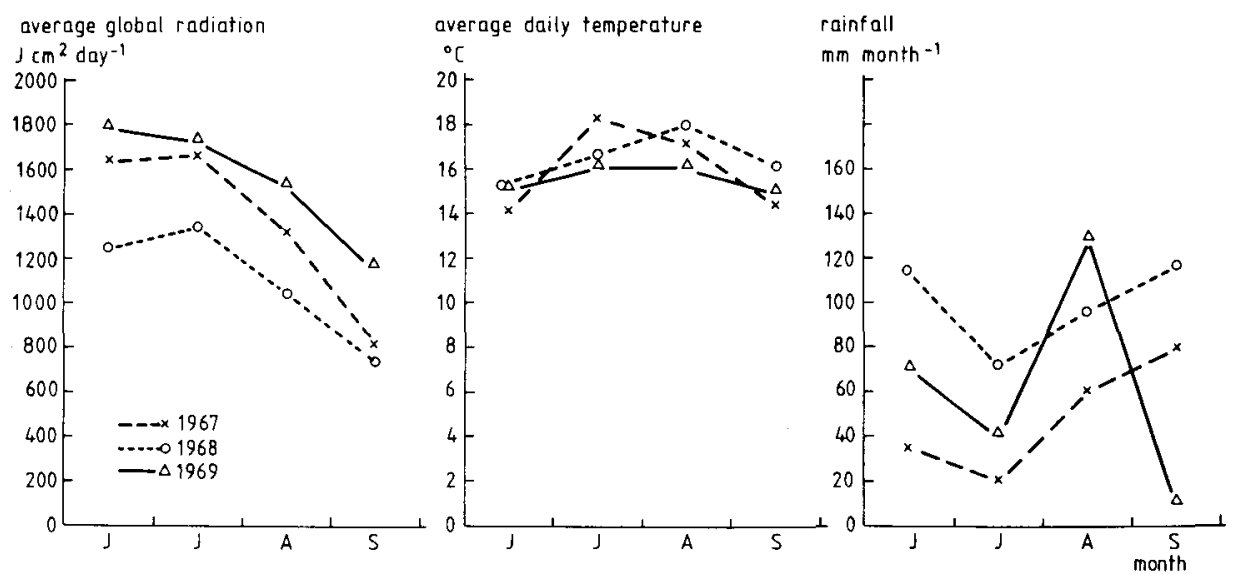

Fig. 1. Average global radiation, temperature and rainfall during June, July, August and September in three successive years. 
was characterized by a rather low average radiation and a fairly high rainfall, whereas the highest average radiation occurred in 1969 combined with a rather low average temperature with a very low rainfall in September.

\section{Results}

Growth, development and tuber yield

The trend in growth and development during the growing period has been presented in Figs 2 and 3.
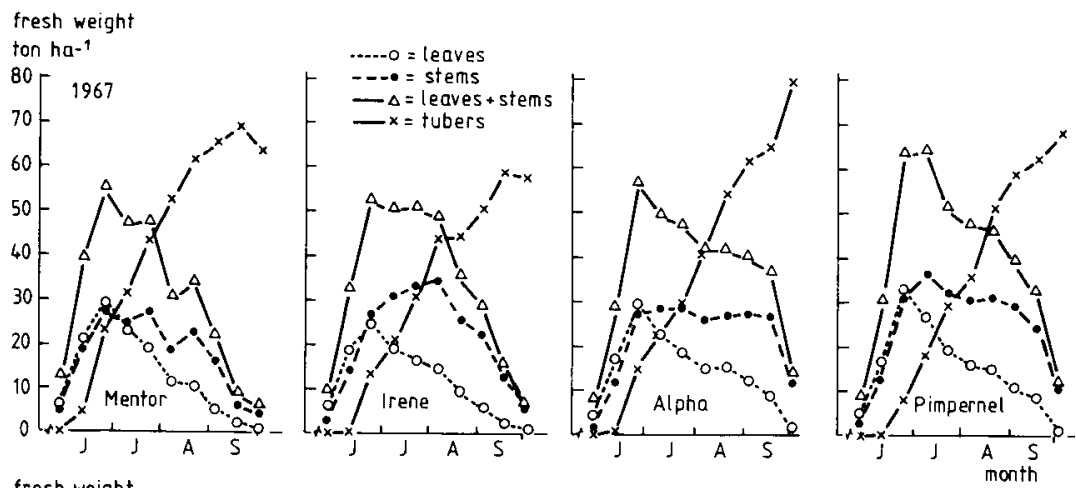

fresh weight
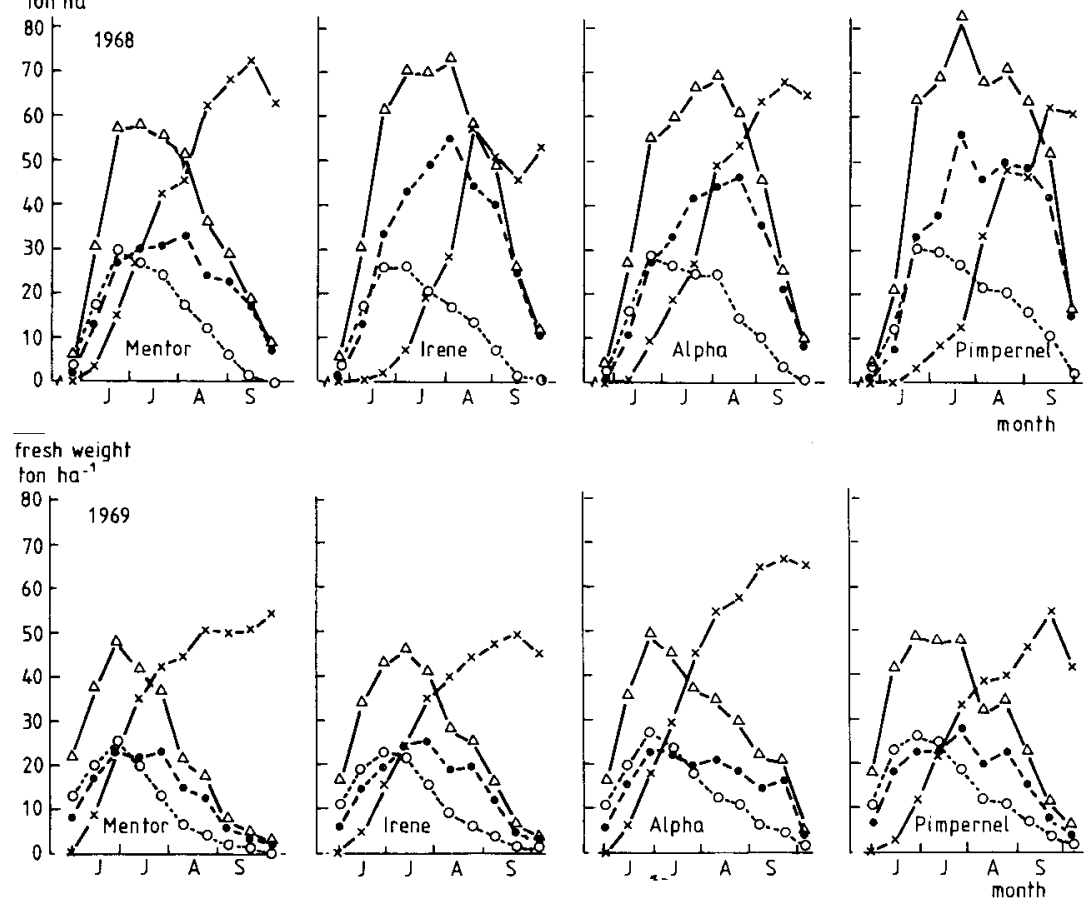

Fig. 2. Fresh weights of leaves, stems, leaves + stems and tubers during the season. 
H. D. GMELIG MEYLING AND K. B. A. BODLAENDER
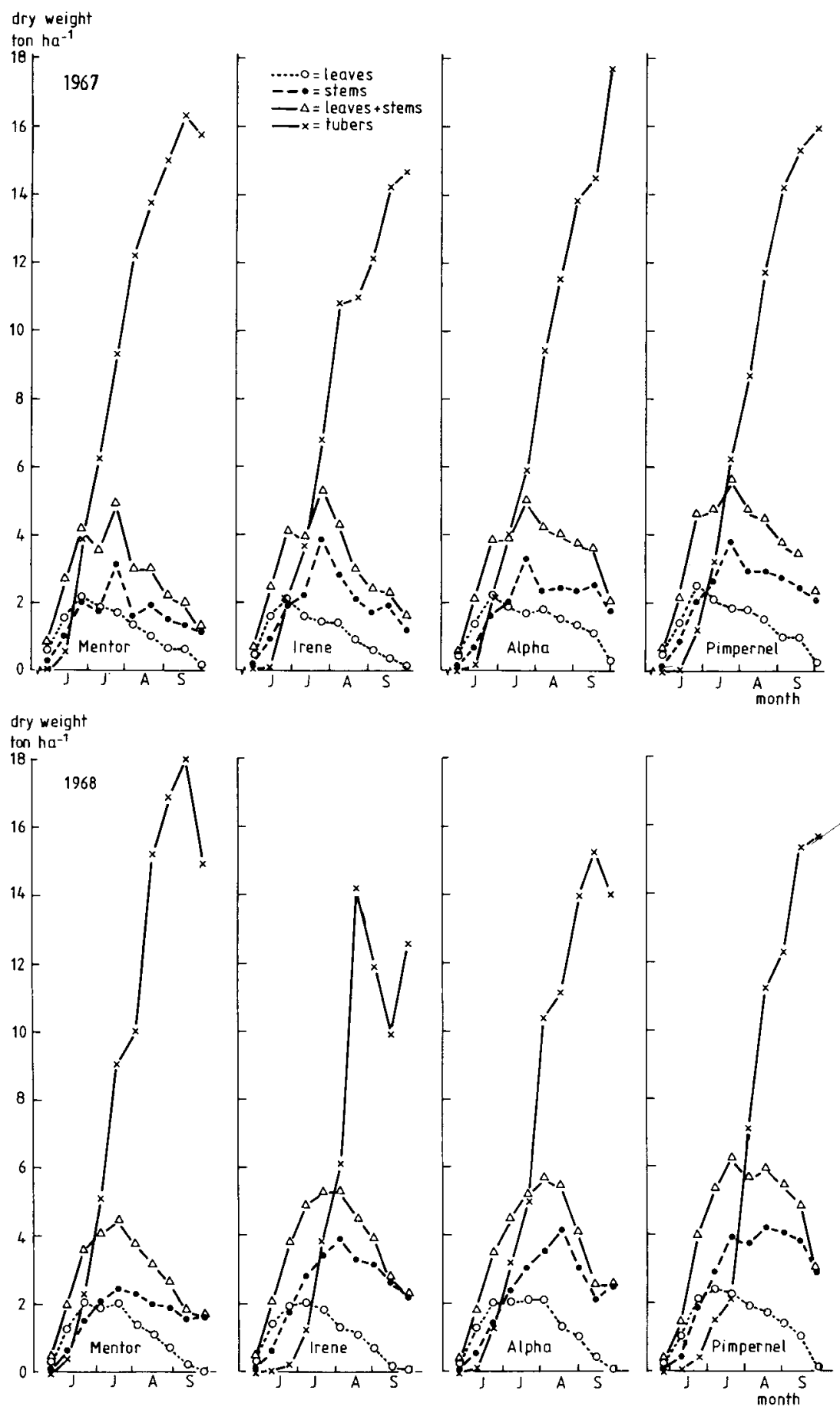

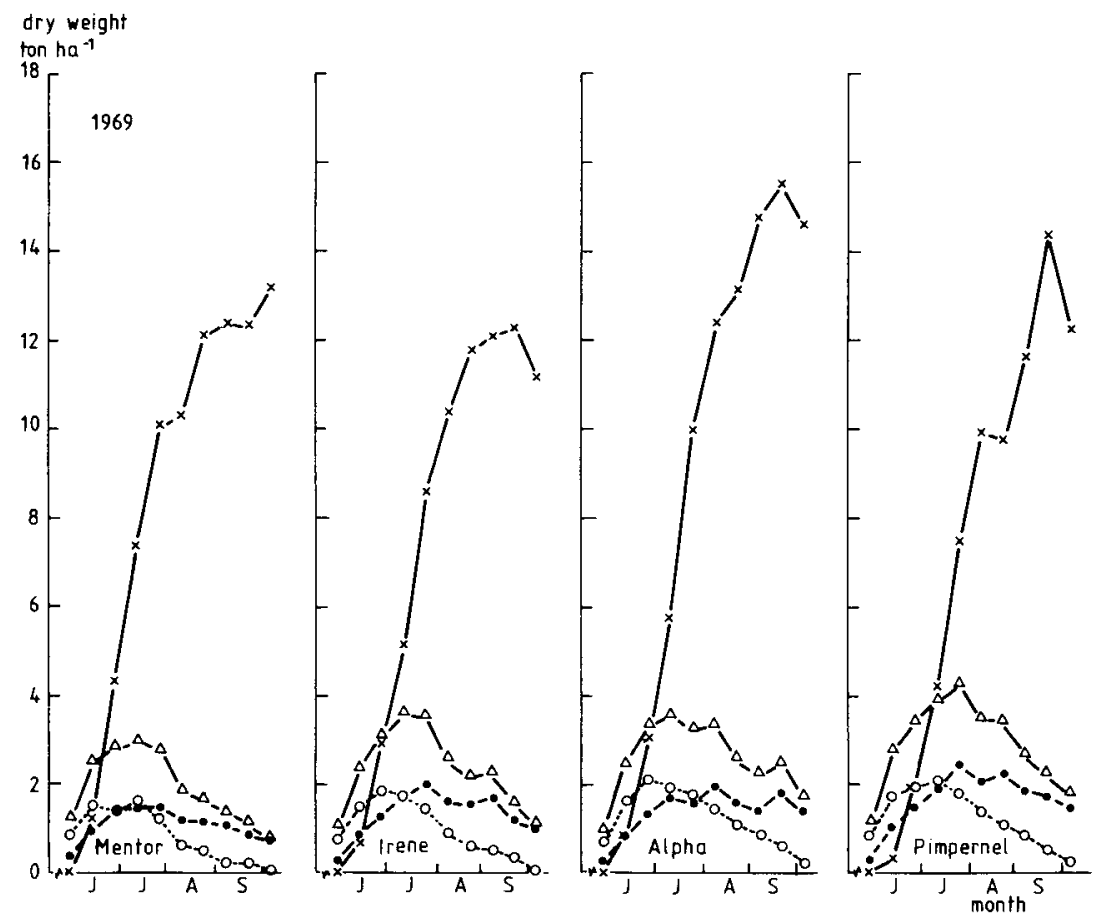

Fig. 3. Dry weights of leaves, stems, leaves + stems, and tubers during the season.

The figures demonstrate that leaf growth in the initial period takes a slight lead over stem growth, but near or after attaining the stage of maximum leaf weight, leaf growth is surpassed by stem growth. So, stem maximum is attained distinctly later than leaf maximum. With regard to maximum leaf weight there are no great differences between the concerning varieties, although in Irene this maximum is somewhat lower compared to the other varieties. Distinct differences are found in the rate at which leaf weights drop (see also LAI values in Table 1). The lowest maximum value for stem weight was found in Mentor, whereas the highest were observed in the varieties Irene and Pimpernel.

With respect to tuber growth also some variation was found in the moment at which tuber growth started. Mentor, for instance, shows a distinct lead over the other varieties. With regard to fresh tuber yields, averaged over three years, the va-

Table 1. Average leaf area index (LAI) on the middle of June, July, August and September.

\begin{tabular}{lllll}
\hline Time & Mentor & Irene & Alpha & Pimpernel \\
& & & & 5.3 \\
15 June & 5.3 & 4.9 & 5.1 & 6.2 \\
15 July & 5.5 & 5.2 & 5.6 & 4.0 \\
15 August & 2.5 & 2.8 & 3.6 & 2.0 \\
15 September & 0.6 & 0.5 & 1.6 & \\
\hline
\end{tabular}


rieties Mentor and Alpha attained higher values than Irene and Pimpernel. Considering tuber dry weights, the yields of Irene are distinctly lower than those of the other three varieties.

Differences between the years are also observed. Relatively slight differences in fresh leaf weights are found, being generally somewhat lower in 1969 than in the other two years. Great differences were obtained in stem weights; stem weights in 1969 being the lowest ones as a result of the combination of a high radiation and a rather low temperature. Also the fresh tuber yields show differences between the years; the largest are obtained in 1967 and the lowest ones in 1969, probably caused by the dry month of September. The tuber dry weights show less distinct differences between the years. The wet season of 1968 caused the largest increase in stem fresh weight and the largest decrease in tuber fresh weight in the variety Irene compared with the results of the more moderate season of 1967.

The trend in the growth rate of the crop (daily total dry matter production per ha) during the growing season (Fig. 4, smoothed lines) shows that some differences occur between the varieties with regard to the maxima attained. Averaged over three years the mean maxima in growth rate for Mentor, Irene, Alpha and Pimpernel were $264,269,247$ and $233 \mathrm{~kg} \mathrm{ha}^{-1} \mathrm{day}^{-1}$, respectively. Another variation is found in the moment at which these maxima are attained: Mentor slightly earlier starts growing at a higher growth rate than the other three varieties. On the other hand, it can be observed that when the growth rates are decreasing, the varieties Alpha and Pimpernel can maintain a somewhat higher growth rate, with an exception in 1968 of the variety Alpha (an average difference of about $50 \mathrm{~kg} \mathrm{ha}^{-1} \mathrm{day}^{-1}$ ), than Mentor and Irene.

\section{Dry matter distribution, growth rate and tuber yield}

The distribution of assimilates to the various parts of the plants is most clearly demonstrated in the relation between tuber and stem weight on August 1 (Fig. 5). The relation between a lower stem weight and a higher tuber yield is fairly distinct, though other effects of e.g. variety and year may have a great influence.

The relation between the dry matter distribution in favour of the tuber $\left(\mathrm{D}^{\mathrm{T}}\right)$ and growth rate (kg total dry matter ha $\left.{ }^{-1} \mathrm{day}^{-1}\right)$ in the month of June is presented in Fig. 6 . The figure demonstrates that distribution of dry matter in favour of the tubers increases at higher growth rates. In this respect Mentor is the most favourable compared to the other varieties, whereas Irene is most affected by annual influences.

Dry matter production, growth duration and tuber yield

The efficiency and size of the leaf apparatus during a certain life span (LAD) is analysed in relation to the total dry matter production (Fig. 7). During a great part of the growing season this relationship is almost linear. Furthermore, a slight intervarietal difference can be observed with regard to the total dry matter produced per LAD unit.

The total dry weights of the liftings with the highest tuber yield (dry) rise distinctly with increasing $L A D$ values (Fig. 8). Intervarietal differences with respect to $L A D$ ultimate values as well as total dry weights are striking. There is also some cor- 

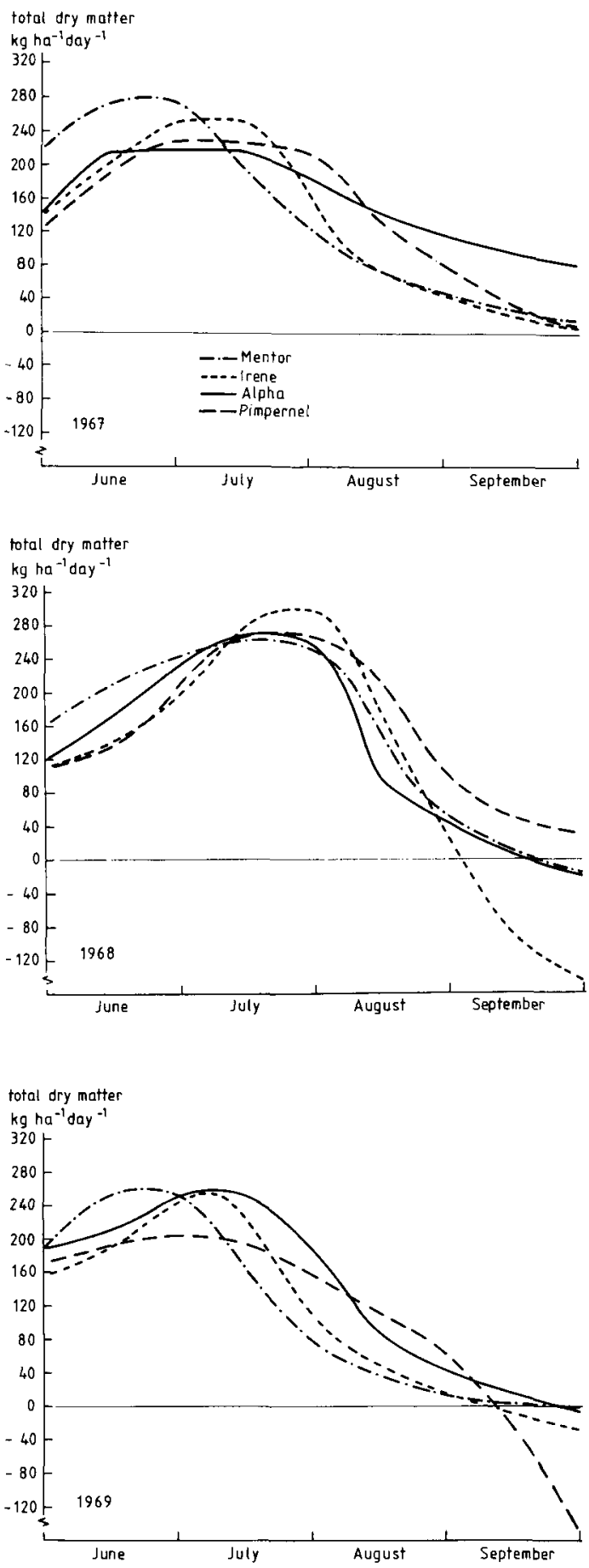

Fig. 4. Growth rate (total dry matter, $\mathrm{kg} \mathrm{ha}{ }^{-1} \mathrm{day}^{-1}$ ) during the season.

Neth. J. agric. Sci. 29 (1981) 


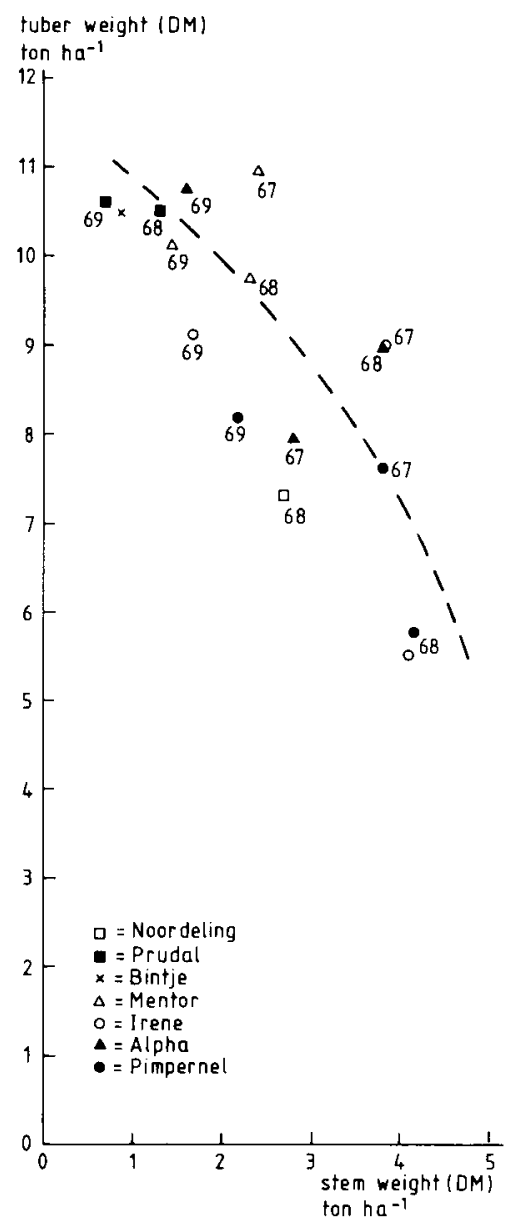

Fig. 5. Relation between tuber and stem weight (DM) on 1 August.

respondence between $\mathrm{LAD}$ and tuber yield, than the dry matter distribution in the first part of the growing season.

Early tuber initiation leads to a dry matter distribution more in favour of the tubers, but it may also lead to a lower total dry weight because the productive period of the leaves is shortened. The ultimate effect on the tuber yield within the genetic limits of a variety is also dependent on weather conditions.

Varietal differences in total dry matter and tuber yield in the two growing periods June and July are generally months with to most favourable growing conditions. In this period the greatest internal competition occurs in the potato between stem and 


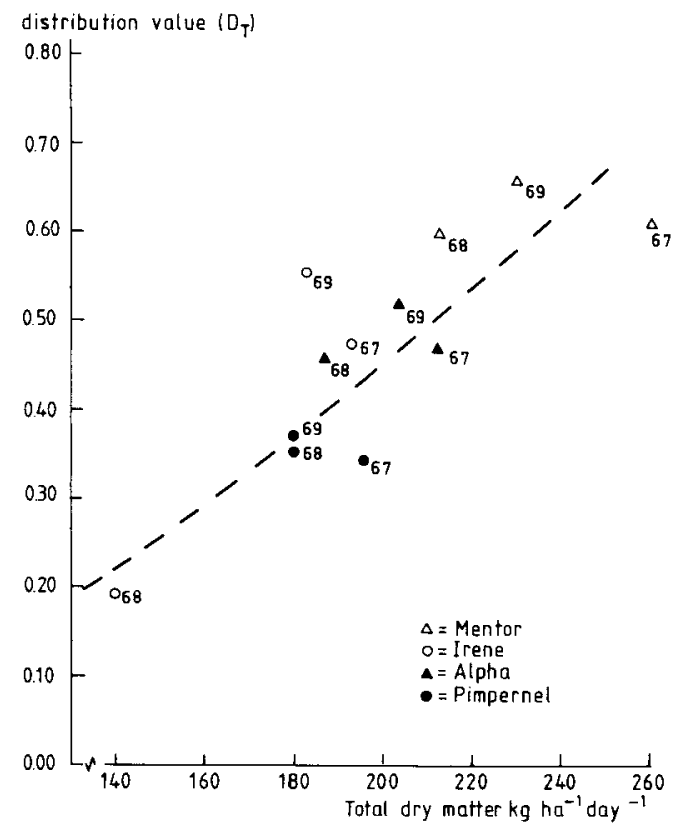

Fig. 6. Relation between distribution value $\left(D_{\mathrm{T}}\right)$ and growth rate (total dry matter, $\mathrm{kg}$ ha $^{-}$day-1) in the period 1 June -1 July.
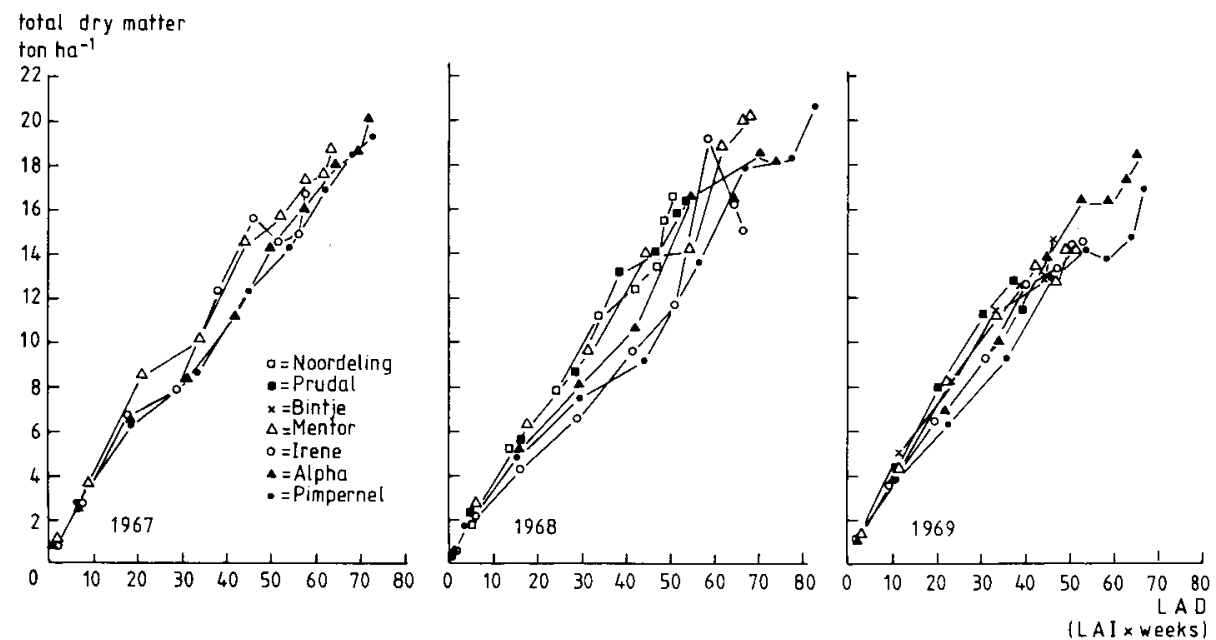

Fig. 7. Relation between total dry weight and leaf area duration (LAD) during the seasons of 1967,1968 and 1969.

The growth parameters and yield data presented in Table 2 and Table 3, show considerable varietal differences. Pimpernel is evidently the variety with the lowest values for tuber growth rate and tuber yield. The relative values show that the intervarietal differences in tuber yield (Table 3 ) are expecially due to differences in the 

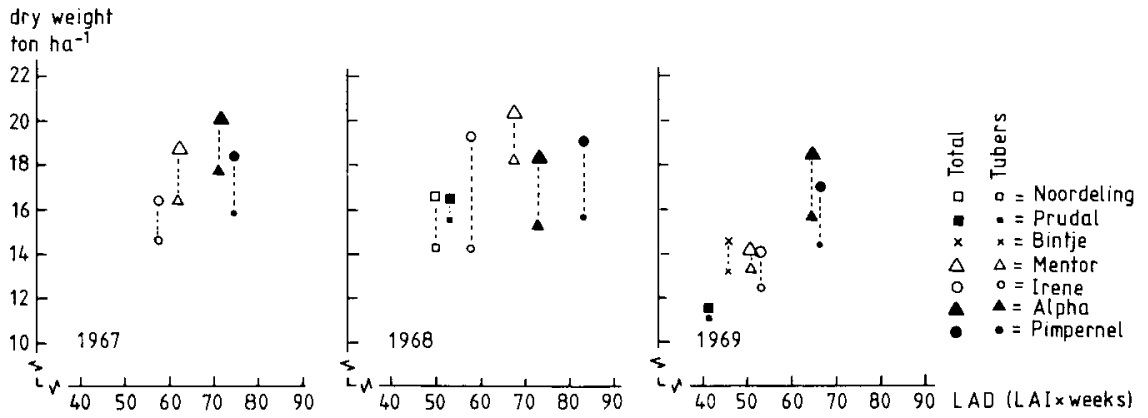

Fig. 8. Relation between the total and tuber dry weight and the leaf area duration (LAD) at the lifting with the highest tuber yield (dry).

distribution of the dry matter and to a less extent to the daily increase of dry matter (Table 2). From the beginning of June until the end of July Mentor had the highest tuber production, Alpha was second, whereas Irene and Pimpernel were the least productive varieties. Attention is called to the fact that the values mentioned with

Table 2. Average crop growth rate (CGR in $\mathrm{kg}$ total dry matter ha ${ }^{-1}$ day $\left.{ }^{-1}\right)$, distribution value $\left(D^{T}\right)^{1}$ and tuber growth rate ( $\mathrm{kg}$ fresh weight $\left.\mathrm{ha}^{-1} \mathrm{day}^{-1}\right)$ in June and July.

\begin{tabular}{llllll}
\hline Variety & Year & Period & CGR & $\mathrm{D}_{\mathrm{T}}{ }^{1}$ & Tuber growth rate \\
Mentor & 1967 & $12 / 6-24 / 7$ & 259 & 0.81 & 792 \\
& 1968 & $10 / 6-22 / 7$ & 267 & 0.76 & 733 \\
& 1969 & $16 / 6-28 / 7$ & 218 & 0.85 & 707 \\
& mean & & 248 & 0.81 & 744 \\
\multirow{5}{*}{ Irene } & rel $^{2}$ & & 120 & 140 & 143 \\
& 1967 & $12 / 6-24 / 7$ & 227 & 0.65 & 636 \\
& 1968 & $10 / 6-22 / 7$ & 176 & 0.55 & 420 \\
& 1969 & $16 / 6-28 / 7$ & 217 & 0.76 & 590 \\
& mean & & 207 & 0.65 & 546 \\
Alpha & rel & & 100 & 112 & 105 \\
& 1967 & $12 / 6-24 / 7$ & 208 & & \\
& 1968 & $10 / 6-22 / 7$ & 200 & 0.66 & 595 \\
& 1969 & $16 / 6-28 / 7$ & 240 & 0.60 & 702 \\
& mean & & 216 & 0.78 & 777 \\
& rel & & 105 & 117 & 692 \\
Pimpernel & & & & 133 \\
& 1967 & $12 / 6-24 / 7$ & 228 & 0.62 & 543 \\
& 1968 & $10 / 6-22 / 7$ & 176 & 0.50 & 446 \\
& 1969 & $16 / 6-28 / 7$ & 213 & 0.61 & 572 \\
& mean & & 206 & 0.58 & 520 \\
& rel & & 100 & 100 & 100 \\
\hline
\end{tabular}

${ }^{1} \mathrm{D}_{\mathrm{T}}=$ (tuber DM increase)/(total DM increase.)

2 Variety with the lowest value of tuber growth rate $=100 \%$. 
Table 3. Total dry weight and tuber yield on 1 August in tonnes ha ${ }^{-1}$.

\begin{tabular}{|c|c|c|c|c|}
\hline \multirow[t]{2}{*}{ Variety } & \multirow[t]{2}{*}{ Year } & \multirow{2}{*}{$\begin{array}{l}\text { Total } \\
\text { DM }\end{array}$} & \multicolumn{2}{|c|}{ Tuber } \\
\hline & & & DM & fresh \\
\hline \multirow[t]{5}{*}{ Mentor } & 1967 & 15.0 & 10.9 & 48.3 \\
\hline & 1968 & 14.0 & 9.7 & 44.7 \\
\hline & 1969 & 13.1 & 10.1 & 43.1 \\
\hline & mean & 14.0 & 10.2 & 45.4 \\
\hline & $r e l^{l}$ & 108 & 142 & 143 \\
\hline \multirow[t]{5}{*}{ Irene } & 1967 & 14.2 & 9.0 & 38.2 \\
\hline & 1968 & 11.1 & 5.5 & 25.6 \\
\hline & 1969 & 12.9 & 9.1 & 36.0 \\
\hline & mean & 12.7 & 7.9 & 33.3 \\
\hline & rell $^{l}$ & 98 & 110 & 105 \\
\hline \multirow[t]{5}{*}{ Alpha } & 1967 & 12.8 & 7.9 & 36.3 \\
\hline & 1968 & 14.8 & 8.9 & 42.8 \\
\hline & 1969 & 14.6 & 10.7 & 47.4 \\
\hline & mean & 14.1 & 9.1 & 42.2 \\
\hline & $\mathrm{rel}^{l}$ & 108 & 126 & 133 \\
\hline \multirow[t]{5}{*}{ Pimpernel } & 1967 & 13.3 & 7.6 & 33.1 \\
\hline & 1968 & 12.4 & 5.7 & 27.2 \\
\hline & 1969 & 13.2 & 8.2 & 34.9 \\
\hline & mean & 13.0 & 7.2 & 31.7 \\
\hline & $\mathrm{rel}^{\mathrm{I}}$ & 100 & 100 & 100 \\
\hline
\end{tabular}

1 Variety with the lowest values of tuber yield $=100 \%$.

regard to tuber growth rates are lower than the actual values, because in this case the average tuber growth rate was calculated from the very first stage of tuber growth. From the beginning of July the values undoubtedly will be higher in all the varieties with only small differences between the varieties.

For the second part of the growing period, apart from some redistribution of assimilates in the foliage, it is mainly the leaf areas still present that determines the daily total dry matter increase (Fig. 9) and this in its turn the rate of tuber production (Fig. 10). It should be noted that according to LAD value, Irene (Fig. 9) shows a lower growth rate than expected. In this period Pimpernel and Alpha are the most productive varieties. Mentor and Irene produce less compared to the first part of the growing period, which is also shown by the data in Table 4.

The effect of varietal differences in both parts of the growing period is expressed in the total dry matter and tuber yield at the final harvest in September (Table 4). Alpha appeared to be the most productive variety, followed by Mentor and Pimpernel, whereas Irene was found to be the least productive. 
Table 4. Total dry weight and tuber yield at the end of September and increase in tuber fresh weight from 1 August till the end of September in tonnes ha- ${ }^{-1}$.

\begin{tabular}{|c|c|c|c|c|c|c|}
\hline \multirow[t]{3}{*}{ Variety } & \multirow[t]{3}{*}{ Year } & \multirow[t]{3}{*}{ Date $^{1}$} & \multicolumn{3}{|c|}{ Yield end of September } & \multirow{3}{*}{$\begin{array}{l}\text { Increase tuber fresh weight } \\
\text { between } 1 \text { August and end of } \\
\text { September }\end{array}$} \\
\hline & & & \multirow{2}{*}{$\begin{array}{l}\text { total } \\
\text { DM }\end{array}$} & \multicolumn{2}{|l|}{ tuber } & \\
\hline & & & & $\mathrm{DM}$ & fresh & \\
\hline \multirow[t]{4}{*}{ Mentor } & 1967 & $25 / 9$ & 17.7 & 16.0 & 66.1 & 17.8 \\
\hline & 1968 & $23 / 9$ & 18.4 & 16.5 & 67.7 & 23.0 \\
\hline & 1969 & $29 / 9$ & 13.7 & 12.8 & 52.2 & 9.1 \\
\hline & mean & & 16.6 & 15.1 & 62.0 & 16.6 \\
\hline \multirow[t]{4}{*}{ Irene } & 1967 & $25 / 9$ & 16.5 & 14.4 & 58.2 & 20.0 \\
\hline & 1968 & $23 / 9$ & 14.0 & 11.3 & 48.0 & 22.4 \\
\hline & 1969 & $29 / 9$ & 13.2 & 11.7 & 47.1 & 11.1 \\
\hline & mean & & 14.6 & 12.5 & 51.1 & 17.8 \\
\hline \multirow[t]{4}{*}{ Alpha } & 1967 & $25 / 9$ & 19.2 & 16.1 & 72.8 & 36.5 \\
\hline & 1968 & $23 / 9$ & 17.4 & 14.6 & 66.3 & 23.5 \\
\hline & 1969 & $29 / 9$ & 17.3 & 15.1 & 65.7 & 18.3 \\
\hline & mean & & 18.0 & 15.3 & 68.3 & 26.1 \\
\hline \multirow[t]{4}{*}{ Pimpernel } & 1967 & $25 / 9$ & 18.8 & 15.6 & 65.0 & 31.9 \\
\hline & 1968 & $23 / 9$ & 19.9 & 15.5 & 61.6 & 34.4 \\
\hline & 1969 & $29 / 9$ & 14.6 & 12.3 & 48.0 & 13.1 \\
\hline & mean & & 17.8 & 14.5 & 58.2 & 26.5 \\
\hline
\end{tabular}

${ }^{1}$ As an average of the two last harvest dates.

\section{Discussion}

The differences in growth and development of the varieties studied on the one side are due to differences in varietal earliness and on the other side to differences within a group of earliness. The effect of varietal earliness was already demonstrated in a study of Wittenrood et al. (1957). Data from the Dutch List of Varieties of Agricultural Crops also indicated this effect (Gmelig Meyling, 1976). Mentor for instance is earlier than Pimpernel which is expressed in the shorter duration of the growing period. This phenomenon was already observed by Reestman (1968).

Besides varietal earliness, early nitrogen deficiency may also lead to rapid senescence and therefore to a shorter growing period. However, in these experiments there was no evidence of a nitrogen deficiency. The nitrogen application in the experiments was rather high. Varietal differences within one group of earliness were to be seen most clearly by a comparison of Mentor and Irene. In Irene stem growth was more pronounced than in Mentor, expecially in 1968 a year with high rainfall; as a result tuber production of Irene is affected more adversely than that of Mentor. The comparison of Pimpernel and Alpha in this respect shows a somewhat similar picture.

Growth rate, as an indication for photosynthesis, partly follows the natural seaso- 


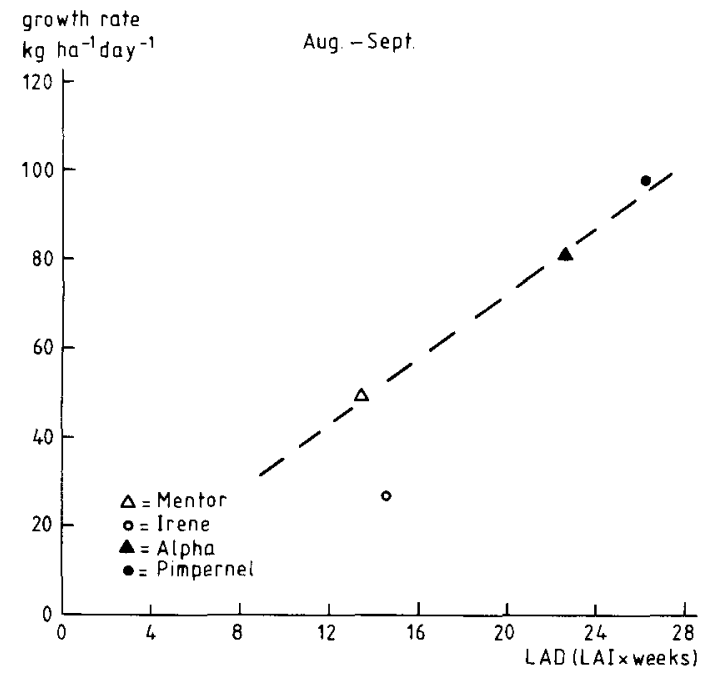

Fig. 9. Relation between growth rate (total dry matter, $\mathrm{kg} \mathrm{ha}^{-1}$ day $^{-1}$ ) and the leaf area duration (LAD) during the second part of the growing period (August and September), averages for three years.

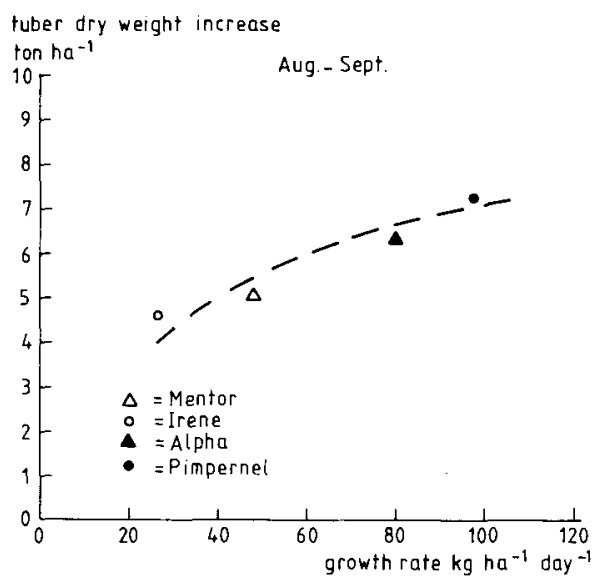

Fig. 10. Relation between increase in tuber dry weight and growth rate (total dry matter, $\mathrm{kg} \mathrm{ha}^{-1} \mathrm{day}^{-1}$ ) during the second pard of the growing period (August and September), averages for three years.

nal trend of the light curve and partly leaf development: an increase until the end of June/beginning of July and then a gradual fall by declining radiation and senescence of the foliage. The growth rate of Mentor, attaining its maximum earlier than the other varieties, may be related to varietal earliness, but it may as well be caused by another varietal difference. The less rapid decrease in the growth rates of Alpha and Pimpernel is caused by a retardation in the senescence of the foliage; both these varieties are later than Mentor and Irene.

The combined effect of daily dry matter production and distribution of the dry matter in the first part of the growing season results in differences in tuber yield at the end of this period. In this case Mentor shows the highest values. In the second part of the growing season, August and September, on the other hand, the size of the leaf apparatus present almost determines the increase of total and tuber yield. The relation between LAD and dry matter production also corresponds with the 
findings of Bremner et al. (1966) and Reestman (1968).

Varietal earliness affects LAD-values, since LAI drops more sharply in early than in late varieties due to more rapid senescence of the foliage. Therefore LAD of the early varieties may be considered as a limiting factor for production. The annual effects on the size of LAD were fairly great, which may be due to the differences in environmental conditions. Such effects were also seen in the study of Nečas (1968).

The differences in efficiency of the leaf apparatus (total dry matter production per LAD unit), as demonstrated by Fig. 6, may be caused by varietal differences in photosynthesis rate and crop structure. This should correspond with the findings of i.a. Meinl (1967) in photosynthesis studies, in which the early varieties showed a higher photosynthesis rate earlier in the growing period than the late varieties.

Relatively early varieties, provided they have a leaf apparatus of reasonable size, can benefit from a favourable leaf efficiency and dry matter distribution in the period June and July which under Dutch conditions is potentially the most favourable (Sibma, 1977).

Reduced stem growth favours tuber growth which was demonstrated by Bodlaender (1978) in a study on the effect of growth retardants. This relationship is also associated which the fact that early varieties generally show less rapid stem growth compared with late ones. The conclusions may be drawn that stem growth as well as tuber growth and development are associated with varietal earliness. Neăs (1968) distinguished in potato varieties leafy, stemmy and intermediate types. Engel \& Raeuber (1962) also found differences in stem growth due to differences in varietal earliness in allometric studies.

Differences in distribution values $\left(\mathrm{D}^{\mathrm{T}}\right)$ are frequently neglected, whereas these may indeed be of importance for the final tuber yield (i.a. Nečas, 1965; Loomis et al., 1971).

The fairly distinct positive relation between dry matter distribution and growth rate might support the hypothesis time and rate of tuber initiation and growth in the initiatal phase (June) determine the extent of photosynthesis (i.a. Gifford, 1965; Nösberger \& Humphries, 1965; Milthorpe \& Moorby, 1966; Moorby, 1970). So a higher growth rate (i.e. rate of photosynthesis) may be due to an advantage in sink formation (tuber growth); however, a parallel trend of both phenomena is also possible. The latter assumption would correspond with the study of Moll \& Henninger (1978) who also found maximum photosynthesis values with leaves of intact plants as well as with isolated leaves where tubers could not function as sinks.

\section{Acknowledgements}

The authors wish to thank Dr. Ir. J. H. J. Spiertz for his valuable comments and criticial remarks. We are very indebted to Miss A. H. van Rossem for translating the manuscript. 


\section{References}

Anonymous, 1969. Rassenlijst voor landbouwgewassen, 44e beschrijvende, IVRO, Wageningen.

Bodlaender, K. B. A., 1978. Growth regulators in potato production. International Course on Potato Production. Centrum voor Agrobiologisch Onderzoek (CABO) Wageningen, Netherlands, p. 1-6.

Bremner, P. M. \& M. A. Take, 1966. Studies in potato agronomy. I. The effect of variety, seed size and spacing on growth, development and yield. J. agric. Sci. Camb.: 241-252.

Bremner, P. M. \& R. W. Radley, 1966. Studies in potato agronomy. Il. The effects of variety and time of planting on growth, development and yield. J. agric. Sci. Camb.: 253-262.

Engel, K. H. \& A. Raeuber, 1962. Das allometrische Wachstum der Kartoffel. Z. FflZüchtung 47: 114119.

Engel, K. H. \& A. Raeuber, 1964. Untersuchungen über den Verlauf der Massenzunahme bei Kartoffeln in Abhängigkeit von Erbgut - und Umwelteinflüssen. Int. Z. Landw. 5: 3-8.

Gifford, R. M., 1965. A growth study on Majestic potato treated with CCC and maleic hydrazide. B.Sc. Thesis, University of Nottingham.

Gmelig Meyling, H. D., 1976. Introduktie tot een onderzoek naar het verband tussen opbrengst en rasvroegheid bij de aardappel. Versl. Centrum agrobiol. Onderz., Wageningen No. 5: 1-14.

Loomis, R. S., W. A. Williams \& A. E. Hall, 1971. Agricultural productivity. Ann. Rev. Pl. Physiol. 22: 431-468.

Meinl, G., 1967. Assimilation als Sortenmerkmal. I. Vergleich der apparten Assimilation von Kartoffelsorten verschiedener Reifezeit. Photosynthetica 1: 51-56.

Milthorpe, F. L. \& J. Moorby, 1966. The growth of the potato. Proc. 3rd trienn. Conf. (Zürich, 4-10 Sept.): 51-70.

Moll, A. \& W. Henniger, 1978. Genotypische Photosyntheserate von Kartoffeln und ihre mögliche Rolle für die Ertragsbildung. Photosynthetica 12 (1): 51-61.

Nečas, J., 1965. Application of growth analysis to potatoes in field culture and some specific of potato growth. Biol. Plantarum (Praha) 7 (3): 180-193.

Nečas, J., 1968. Growthanalytical approach to the analysis of yielding capacity of potato varieties. Photosynthetica 2 (2): 85-100.

Reestman, A. J., 1968. lets over het produktiepatroon van de aardappel. In: Landbouwplantenteelt. Directie van Landbouwonderwijs, Ministerie van Landbouw en Visserij, Den Haag: 88-121.

Sibma, L., 1977. Maximization of arable crop yield in the Netherlands. Neth. J. agric. Sci. 25: 278-287.

Wittenrood, H. G., A. J. Reestman \& K. B. A. Bodlaender, 1957. Groei en produktie van aardappelen. Jaarb. Inst. biol. Scheik. Onderz. Landb. gewassen, Wageningen. 95-115. 